\title{
Studi Eksperimen Pengaruh Variasi Pegas Kopling Terhadap Gaya Dorong dan Percepatan Pada Kendaraan Yamaha Vixion $150 \mathrm{cc}$
}

\author{
Reza Prakoso Ramadhan dan I Nyoman Sutantra \\ Jurusan Teknik Mesin, Fakultas Teknik Industri, Institut Teknologi Sepuluh Nopember (ITS) \\ Jl. Arief Rahman Hakim, Surabaya 60111 Indonesia \\ e-mail: tantra@me.its.ac.id
}

\begin{abstract}
Abstrak - Saat ini perkembangan dunia otomotif khususnya sepeda motor terus dikembangkan untuk mendapatkan kenyamanan dalam pengendalian. Produsen otomotif khususnya roda dua (sepeda motor) telah memproduksi kendaraan berkapasitas besar . Para produsen berlomba lomba untuk menciptakan kedaraan dengan performa dan akselerasi yang baik . Akselerasi dan performa yang baik salah satunya dipengaruhi oleh tingkat kekakuan dari pegas kopling. Dengan banyaknya variasi dari pegas kopling yang dijual di pasaran dan memiliki nilai konstanta yang berbeda beda mengindikasikan bahwa pemilihan pegas kopling yang sesuai dapat memperbaiki performa dari kendaraan standart. Dan ini yang mendasari terlaksananya penelitian kali ini. Pada penelitian ini data yang ingin diperoleh adalah gaya dorong, percepatan. Hasil dari pengujian ini adalah pegas dengan nilai konstanta 13,05 $\mathrm{N} / \mathrm{mm}$ menghasilkan nilai gaya dorong terbesar dibandingkan pegas dengan nilai konstanta 8,29 $\mathrm{N} / \mathrm{mm}$ yaitu sebesar $509,805 \mathrm{~N}$ untuk nilai gaya dorong dan $4,42 \mathrm{~m} / \mathrm{s}^{2}$ untuk nilai percepatan. Ini menandakan bahwa pegas dengan nilai konstanta pegas yang besar enghasilkan performa yang baik untuk kendaraan.
\end{abstract}

Kata Kunci — Pegas kopling, transmisi manual

\section{PENDAHULUAN}

$\mathrm{K}$ EMAJUAN teknologi mempengaruhi berbagai aspek kehidupan baik ekonomi, politik, sosial, dan budaya. Dunia otomotif, baik mobil maupun motor selalu mengalami kemajuan. Kopling yang terdapat pada kendaraan berfungsi untuk melakukan perpindahan tingkat transmisi serta membantu meningkatkan performa dan akselerasi kendaraan. Fenomena yang terjadi di masyarakat sekarang, Banyak masyarakat yang ingin mengganti pegas kopling yang terpasang pada kendaraan dengan pegas kopling variasi yang dirasa bisa meningkatkan performa serta akselerasi kendaraan. Maka dari itu perlu dilakukan adanya analisa mendalam untuk mengetahui pengaruh dari penggantian pegas kopling tersebut serta mengetahui varian pegas kopling mana yang cocok digunakan pada kendaraan yamaha vixion $150 \mathrm{cc}$.

\section{URAIAN PENELITIAN}

\section{A. Transmisi Kendaraan}

Untuk menggerakkan kendaraan dibutuhkan gaya dorong yang cukup untuk melawan semua hambatan yang terjadi pada kendaraan. Gaya dorong dari suatu kendaraan terjadi pada roda penggerak kendaraan. Gaya dorong ini ditransformasikan dari torsi mesin kendaraan ke roda penggerak yang terdiri dari kopling, transmisi, gigi diferensial, dan poros penggerak. Berdasarkan kebutuhan gerak dari kendaraan, maka dapat dikatakan bahwa pada kecepatan rendah diperlukan gaya dorong yang besar untuk dapat menghasilkan percepatan yang cukup besar atau untuk dapat menanjak tanjakan yang cukup terjal. Dengan kebutuhan seperti diuraikan di atas, secara ideal kebutuhan gaya dorong dapat ditunjukkan seperti gambar 1 .

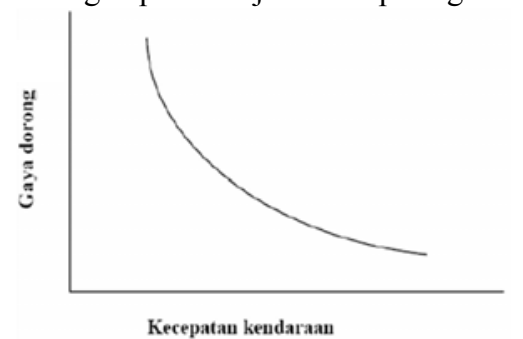

Gambar 1. Gaya Dorong yang dibutuhkan Kendaraan [1]

\section{B. Kopling Pada Kendaraan}

Kendaraan dengan transmisi manual biasanya beroperasi dengan menggunakan bantuan kopling. Sistem kopling yang ada di kendaraan bermotor mempunyai banyak ragamnya. Salah satu contohnya adalah dengan melihat gambar kopling yang ada pada kendaraan bermotor seperti pada gambar 2 yaitu mekanisme ketika dilakukan pertambahan tingkat transmisi atau ketika handle kopling ditekan.

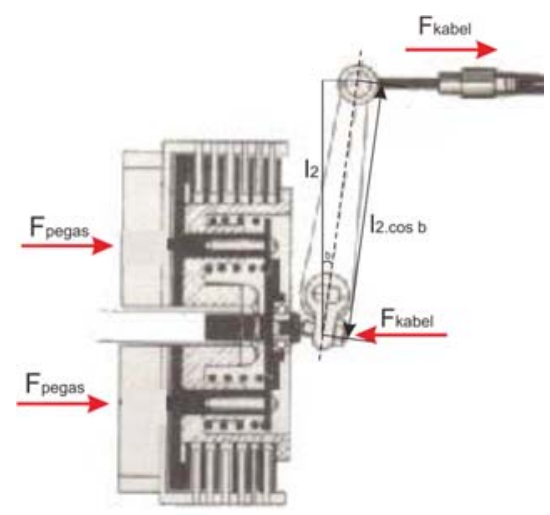

Gambar 2 Kopling pada kendaraan. ${ }^{[3]}$

dimana pada gambar terlihat bahwa ketika dilakukan mekanisme kopling pegas kopling ditekan oleh batang penekan yang mengakibatkan pasngan pegas kopling dan kampas kopling merenggang. Sehingga daya tidak tersalur ke poros output. Berbeda ketika handle kopling dilepas dapat dilihat pada gambar 4 . 


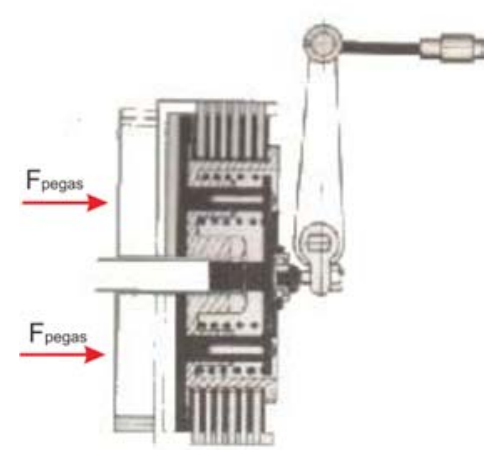

Gambar 3 Kopling pada kendaraan [3]

Pada kondisi ini pegas kopling memberikan gaya kepada pasangan kapas kopling sehingga menghasilkan power yang baik untuk kendaraan.

\section{Kinematika Pegas Heliks Tekan}

Pegas Heliks tekan kebanyakan memiliki dimensi yang konstan pada diameter kawat, pitch, dan diameter rata-rata coil. Gambar 2.19 ini menunjukkan parameter dimensi dari pegas heliks tekan.

Sehingga,

$\mathrm{Do}=\mathrm{D}+\mathrm{d}$ dan $\mathrm{Di}=\mathrm{D}-\mathrm{d}$

dimana :

$\mathrm{d}=$ diameter kawat

Do $=$ diameter luar coil

$\mathrm{D}=$ diameter rata-rata coil

$\mathrm{hf}=$ tinggi bebas

$\mathrm{Di}=$ diameter dalam coil

$\mathrm{p}=$ pitch coil

Diameter luar (Do) coil, diameter dalam (Di) coil, dan tinggi bebas (hf) adalah parameter utama yang digunakan untuk menentukan batas, berdasarkan pada tempat dimana pegas tersebut diletakkan.

Pada gambar 5, tinggi bebas (hf) adalah tinggi pegas pada kondisi tanpa pembebanan. Beban kerja yang terjadi pada pegas (F) akan menekan pegas sebesar defleksi kerja $(\delta)$.

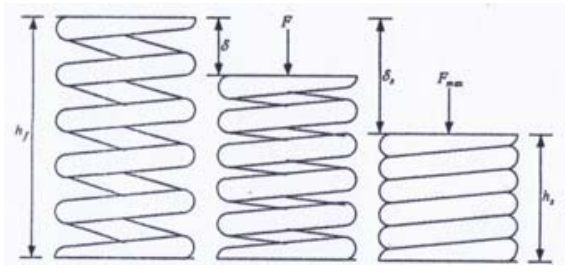

Gambar 4. Kondisi Pegas Dengan Beban Kerja ${ }^{[2]}$

Untuk beban kerja yang terjadi pada pegas itu maksimum (Fmax) maka tinggi pegas (hs). Dari dimana diatas maka didapatkan beberapa persamaan :

$$
\begin{aligned}
& \delta=\frac{F}{k}=\frac{8 F D^{3} N a}{d^{4} G} \\
& \mathrm{hf}=\mathrm{hs}+\delta \mathrm{s}
\end{aligned}
$$

dimana :

hf : tinggi bebas

hs : tinggi solid

$\delta$ s $\quad$ defleksi karena beban material

G : Modulus geser material

$\mathrm{F} \quad$ : beban kerja

$\mathrm{Na}$ : lilitan aktif

$\mathrm{K} \quad$ : konstanta pegas
1) Lilitan Pegas

Lilitan total dari pegas, bergantung dari jenis ujung pegas. Jenis ujung pegas mempunyai 4 macam, yaitu :

1. Plain ends $\quad \mathrm{Na}=\mathrm{Nt}-1 / 2$

2. Plain grounds ends $\mathrm{Na}=\mathrm{Nt}-1$

3. Squared ends $\mathrm{Na}=\mathrm{Nt}-1 \frac{1}{2}$

4. Squared grounds ends $\mathrm{Na}=\mathrm{Nt}-2$

dimana :

$\mathrm{Na}=$ lilitan aktif pegas

$\mathrm{Nt}=$ lilitan aktif total pegas

2) Indeks Pegas

Indeks pegas adalah perbandingan dari diameter rata-rata coil (D) terhadap diameter kawat (d).

Maka persamaan : $\mathrm{c}=\frac{D}{d}$

3) Konstanta Pegas

Untuk menentukan persamaan dari konstanta pegas $(\mathrm{k})$ adalah

$$
\mathrm{k}=\frac{F}{\delta}=\frac{d^{4} G}{8 D^{3} N a}
$$

Pegas heliks tekan orisinil memiliki konstanta pegas yang linier terhadap batas operasinya seperti pada gambar 2.20. Saat terjadi tinggi solid (hs) semua saling bersentuhan dan konstanta pegas mendekati nilai modulus elastisitas dari material.

\section{Gaya Dorong Kendaraan}

Gaya dorong kendaraan didefinisikan sebagai kemampuan kendaraan untuk dipercepat, dan mengatasi hambatan-hambatan yang terjadi, diantaranya hambatan rolling ban (rolling resistance), hambatan aerodinamis, dan hambatan tanjakan. Kemampuan kendaraan tersebut sangat dipengaruhi oleh kemampuan mesin kendaraan dan pemilihan tingkat serta rasio transmisi. Gaya-gaya tersebut secara free body diagram akan dijelaskan pada gambar 4.

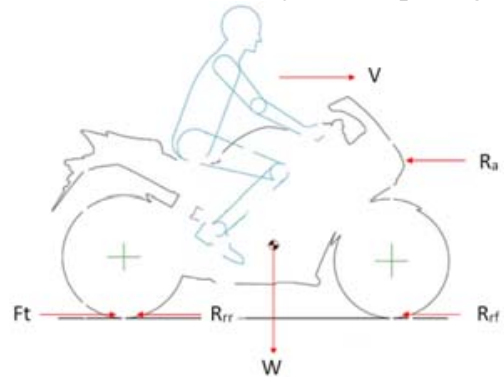

Gambar 5. FBD Gaya Dorong, Kecepatan, Percepatan dan Gaya Hambat [4]

$$
\begin{aligned}
& F t=\frac{T e \cdot i t \cdot i g \cdot \eta t}{r} \\
& i t=\frac{n e}{n t r}
\end{aligned}
$$

Dari karakteristik torsi mesin $\left(\mathrm{T}_{\mathrm{e}}\right)$, terliha( (da)wa torsi sebagai fungsi dari putaran mesim:13Adapun hubungan kecepatan dan putaran mesin dapat dirumuskan pada persamaan 3

$$
V=\frac{n e .2 \pi \cdot r}{\text { it } . i g .60}(1-S)
$$

Besarnya percepatan kendaraan pada jalan datar dirumuskan pada persamaan 4

$$
a=\frac{F t-R a-R r}{\mathrm{M}}
$$




\section{E. Aerodynamic Resistance}

Aerodynamic Resistance adalah gaya hambat yang terjadi berlawanan arah dengan kendaraan secara horizontal pada kecepatan tertentu. Nilai gaya hambat ini dipengaruhi oleh koefisien drag, densitas udara, kecepatan kendaraan, dan luas frontal kendaraan yang secara matematis dapat dilihat pada persamaan 5

$\mathrm{Ra}=1 / 2 \cdot \rho \cdot \mathrm{Cd} \cdot \mathrm{V} 2 . \mathrm{Af}$

Berikut tabel koefisien aerodynamic untuk berbagai jenis kendaraan.

Tabel 1.Koefisien Aerodynamic Resistance untuk Kendaraan ${ }^{[4]}$

\begin{tabular}{ll}
\hline \hline Jenis Kendaaraan & Koefisien Hambat \\
\hline Kendaraan penumpang & $0,3-0,6$ \\
Kendaraan convertible & $0,4-0,65$ \\
Kendaraan balap & $0,25-0,3$ \\
Bus & $0,6-0,7$ \\
Truck & $0,8-1,0$ \\
Tractor - trailer & $0,8-1,3$ \\
\hline \hline
\end{tabular}

\section{F. Grade Resistance}

Gaya hambat akibat sudut tanjak adalah gaya hambat yang terjadi karena adanya sudut pada lintasan kendaraan sehingga terjadi perubahan gaya pada kendaraan. Perubahan sudut lintasan ini menyebabkan rolling resistance berubah maupun berat kendaraan. Perubahan gaya - gaya tersebut dapat dilihat pada gambar 5 .

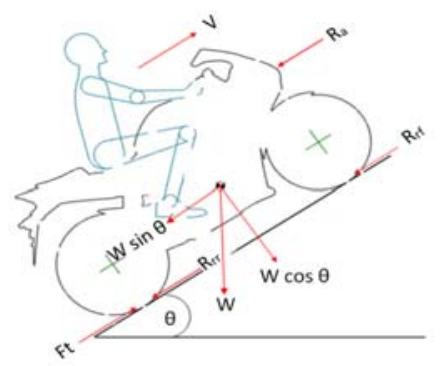

Gambar 6. Diagram Bodi Bebas Kendaraan Saat Menanjak [4]

Berikut terdapat penambahan gaya dari berat kendaraan yang dikalikan dengan sudut tanjakannya.

$$
\mathrm{Ft}=\mathrm{Rr}+\mathrm{Ra}+\mathrm{W} \sin \theta \max
$$

Serta perubahan persamaan rolling resistance dikalikan dengan sudut tanjakannya.

$$
\mathrm{Rr}=\mathrm{fr} . \mathrm{W} \cos \theta \max
$$

\section{G. Dynotest}

Dinamometer atau dyno test adalah sebuah alat yang digunakan untuk mengukur putaran mesin/RPM dan torsi dimana tenaga/daya yang dihasilkan dari suatu mesin atau alat yang berputar dapat dihitung. Dyno yang dapat mengukur daya dan torsi tanpa memindahkan mesin kendaraan dari rangka kendaraan yang dikenal sebagai sebuah Dinamometer rangka - chassis dyno. Dinamometer rangka adalah suatu alat uji otomotif yang digunakan untuk mengukur daya sebenarnya yang diberikan motor kepada roda-roda penggerak. Dalam tugas akhir ini akan digunakan dyno test dengan jenis dinamometer rangka / chasis dyno dimana mesin tidak dipisahkan oleh chasis sepeda motor. Pada pengujian kali ini jenis dynotest yang digunakan adalah jenis chassis dyno dimana skema pengujian dapat dilihat pada gambar 8 dan pada pengujian ini parameter yang didapat adalah nilai torsi roller, engine power, kecepatan kendaraan setiap tingkat transmisi, dan engine rpm .

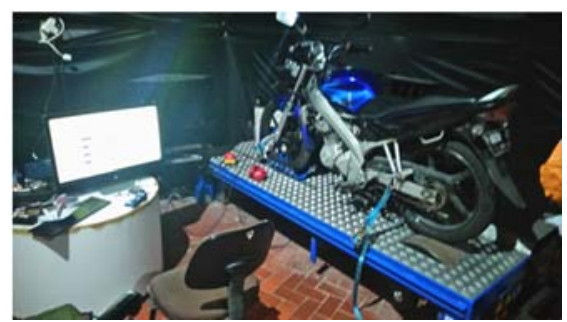

Gambar 7. Skema pengujian kendaraan.

Adapun tahap - tahap yang dilakukan pada pengujian tugas akhir ini adalah sebagai berikut.

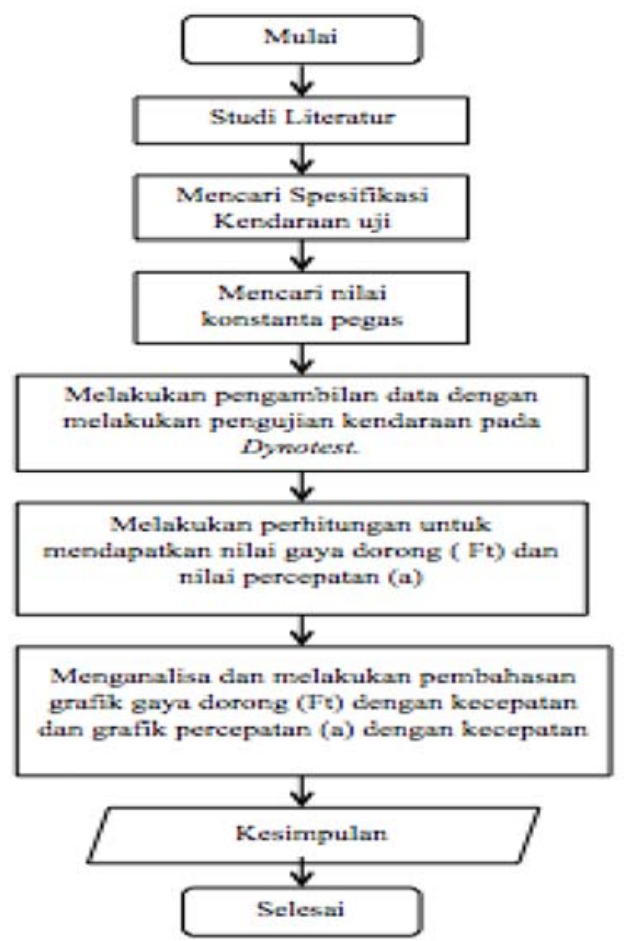

Gambar 8. Prosedur Penelitian

Tahap awal dari penelitian ini adalah dilakukan studi literatur, yaitu merumuskan permasalahan yang terjadi dan mengkaji permasalahan tersebut. Kajian bisa dilakukan melalui buku, jurnal, dan penelitian-penelitian terdahulu. Tahap kedua adalah penentuan jenis kendaraan yang akan dijadikan obyek penelitian. Pada penelitian ini, kendaraan yang akan diuji dan dianalisa adalah Yamaha Vixion $150 \mathrm{cc}$. Tahap ketiga yaitu setelah diperoleh data kendaraan melalui pengujian, maka akan dilakukan analisa pengaruh dari keempat macam pegas kopling kendaraan terhadap performa kendaraan.

\section{H. Prosedur Pengujian Kendaraan.}

Adapun tahap - tahap proses pengujian kendaraan pada dynotest yang dilakukan di workshop Molina ITS adalah sebagai berikut : 
1. Menyiapkan obyek penelitian, alat dynotest, dan pegas kopling /per kopling

2. Menaikan kendaraan ke atas alat dynotest

3. Menyalakan mesin kendaraan dan memutar handle throttle hingga kemampuan mesin maksimum

4. Mengulangi langkah 1-3 dengan mengganti pegas kopling yang lain

5. Data torsi, daya, dan putaran mesin yang dihasilkan keempat pegas kopling dapat dilihat pada layar alat dynotest.

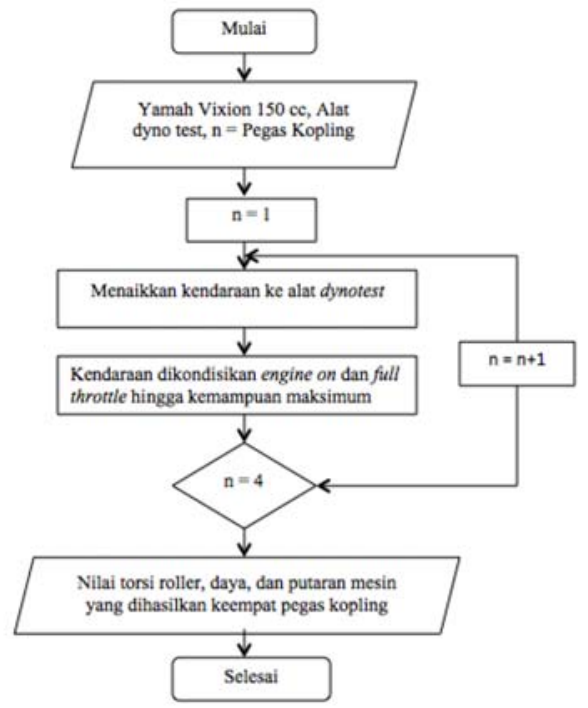

Gambar 9. Flowchart Pengujian Kendaraan

\section{HASIL DAN ANALISA}

\section{A. Data Hasil Spesifikasi Pegas Kopling}

Pada tabel 2 merupakan data hasil spesifikasi pegas kopling yang telah dilakukan. Dari data hasil pengukuran tersebut terlihat perbedaan spesifikasi mulai dari diamerter kawat dan tinggi bebas dari masing - masing Ppegas kopling.

Tabel 2. Data Hasil Spesifikasi pegas kopling

\begin{tabular}{|c|c|c|c|c|}
\hline \multirow[b]{2}{*}{ Spesifikasi } & \multicolumn{4}{|c|}{ PEGAS KOPLING } \\
\hline & TDR & HRP & $\begin{array}{l}\text { KAWAH } \\
\text { ARA }\end{array}$ & ORI \\
\hline $\begin{array}{l}\text { Diameter Dalam } \\
(\mathrm{mm})\end{array}$ & $\begin{array}{l}12.46 \\
\mathrm{~mm}\end{array}$ & $\begin{array}{l}12.97 \\
\mathrm{~mm}\end{array}$ & $\begin{array}{l}12.35 \\
\mathrm{~mm}\end{array}$ & $\begin{array}{l}10.12 \\
\mathrm{~mm}\end{array}$ \\
\hline $\begin{array}{l}\text { Diameter Luar ( } \\
\mathrm{mm})\end{array}$ & $\begin{array}{l}17.65 \\
\mathrm{~mm}\end{array}$ & $\begin{array}{l}18.10 \mathrm{~m} \\
\mathrm{~m}\end{array}$ & $\begin{array}{l}18.30 \\
\mathrm{~mm}\end{array}$ & $\begin{array}{l}17.13 \\
\mathrm{~mm}\end{array}$ \\
\hline $\begin{array}{l}\text { Diameter rata - } \\
\text { rata }(\mathrm{mm})\end{array}$ & $\begin{array}{l}15.05 \\
\mathrm{~mm}\end{array}$ & $\begin{array}{l}15.53 \\
\mathrm{~mm}\end{array}$ & $\begin{array}{l}15.32 \\
\mathrm{~mm}\end{array}$ & $\begin{array}{l}13.62 \\
\mathrm{~mm}\end{array}$ \\
\hline $\begin{array}{l}\text { Diameter Kawat } \\
(\mathrm{mm})\end{array}$ & $\begin{array}{l}2.3 \\
\mathrm{~mm}\end{array}$ & $2.4 \mathrm{~mm}$ & $2.69 \mathrm{~mm}$ & $\begin{array}{l}2.40 \\
\mathrm{~mm}\end{array}$ \\
\hline Pitch Coil ( mm) & $\begin{array}{l}3.37 \\
\mathrm{~mm}\end{array}$ & $\begin{array}{l}4.12 \\
\mathrm{~mm}\end{array}$ & $5.16 \mathrm{~mm}$ & $\begin{array}{l}3.57 \\
\mathrm{~mm}\end{array}$ \\
\hline $\begin{array}{l}\text { Tinggi } \quad \text { Bebas } \\
(\mathrm{mm})\end{array}$ & $\begin{array}{l}39.42 \\
\mathrm{~mm}\end{array}$ & $\begin{array}{l}40.93 \\
\mathrm{~mm}\end{array}$ & $\begin{array}{l}44.41 \\
\mathrm{~mm}\end{array}$ & $\begin{array}{l}36.31 \\
\mathrm{~mm}\end{array}$ \\
\hline Lilitan Aktif & 7 & 7 & 7 & 7 \\
\hline $\begin{array}{l}\text { Konstanta Pegas } \\
\mathrm{N} / \mathrm{mm}\end{array}$ & $\begin{array}{l}10.08 \\
\mathrm{~N} / \mathrm{mm}\end{array}$ & $\begin{array}{l}13.05 \\
\mathrm{~N} / \mathrm{mm}\end{array}$ & $\begin{array}{l}14.46 \\
\mathrm{~N} / \mathrm{mm}\end{array}$ & $\begin{array}{l}8.29 \\
\mathrm{~N} / \mathrm{mm}\end{array}$ \\
\hline
\end{tabular}


Terlihat pegas dengan nilai konstanta $14,46 \mathrm{~N} / \mathrm{mm}$ menghasilkan gaya dorong terbesar yaitu $602,809 \mathrm{~N}$. dibandingkan dua pegas variasi dan satu pegas standart.

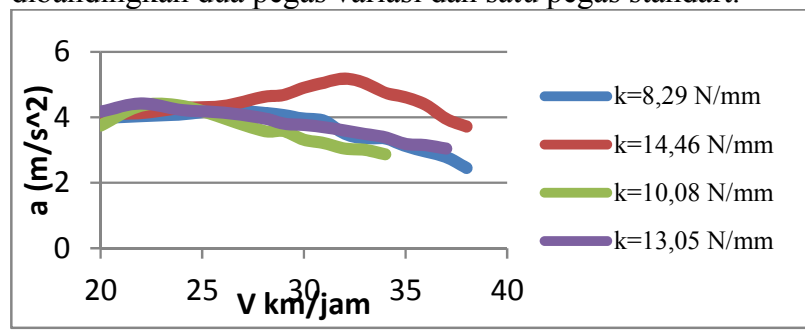

Gambar 13. Grafik Percepatan Setiap Variasi Pegas Pada Tingkat Transmisi Pertama

Sedangkan pada grafik percepatan terlihat bahwa pegas dengan nilai konstanta 14,46 N/mm menghasilkan nilai percepatan yang besar diantara yang lainnya yaitu sebesar $5,18 \mathrm{~m} / \mathrm{s}^{2}$.

D. Grafik Gaya Dorong dan Percepatan Setiap Variasi Pegas Pada Tingkat Transmisi Kedua.

Berikut adalah grafik gaya dorong pada tingkat transmisi kedua .

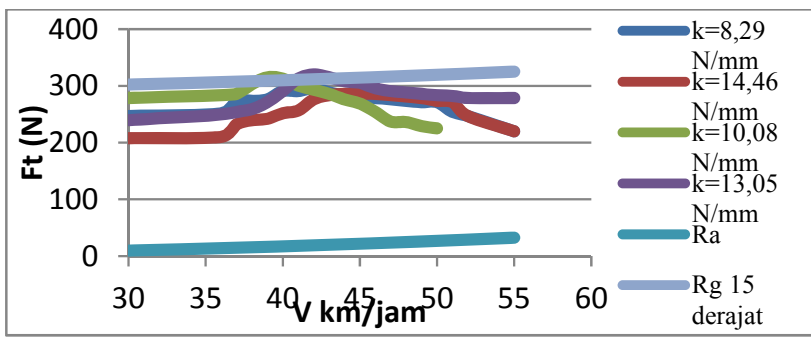

Gambar 14. Grafik Gaya Dorong Beserta Gaya Hambat Setiap Variasi Pegas Pada Tingkat Transmisi Kedua.

Pada gambar 14 dapat dilihat bahwa pegas dengan nilai konstanta 13,05 N/mm lebih unggul dibandingkan pegas yang lain dengan nilai gaya dorong sebesar 320,295 N/mm.

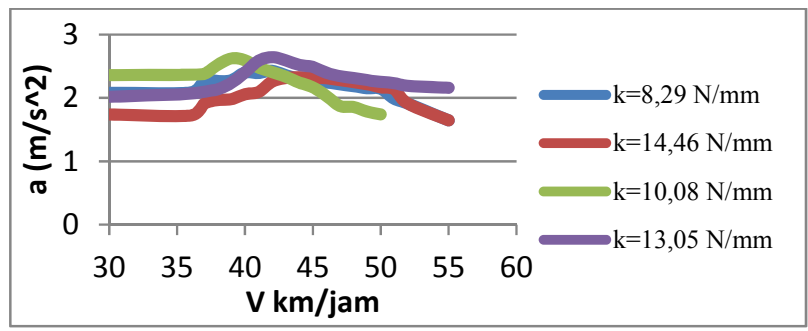

Gambar 15. Grafik Percepatan Setiap Variasi Pegas Pada Tingkat Transmisi Kedua.

Sedangkan pada percepatan di tingkat transmisi kedua dimana pegas dengan nilai $13,05 \mathrm{~N} / \mathrm{mm}$ menghasilkan nilai percepatan terbesar yaitu sebesar $2,64 \mathrm{~m} / \mathrm{s}^{2}$. Hal ini diakibatkan beberapa hal teknis seperti servis rutin dang anti oli kendaraan sebelum dilakukan pengujia dynotest agar power yng dihasilkan kendaraan semakin baik.

\section{E. Grafik Gaya Dorong dan Percepatan Setiap Variasi Pegas Pada Tingkat Transmisi Ketiga.}

Berikut ini adalah grafik perbandingan gaya dorong dan percepatan setiap variasi pegas. Pada gambar 14 terlihat bahwa pada grafik gaya dorong kendaraan pegas dengan nilai konstanta $13,05 \mathrm{~N} / \mathrm{mm}$ menghasilkan gaya dorong terbesar yaitu sebesar 232,927 N.

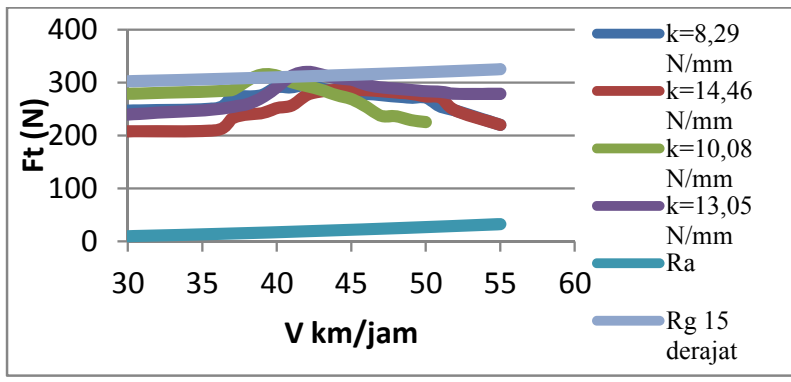

Gambar 16. Grafik Gaya Dorong Setiap Variasi Pegas Pada Tingkat Transmisi Ketiga

Sedangkan pada grafik percepatan ditunjukkan pada gambar 17 dimana nilai percepatan terbesar dihasilkan oleh pegas kopling dengan nilai konstanta 13,05 N/mm yaitu sebesar $1,74 \mathrm{~m} / \mathrm{s}^{2}$.

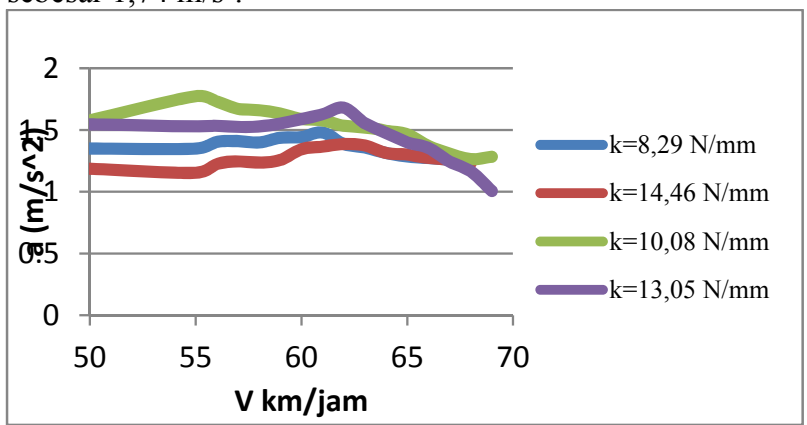

Gambar 17. Grafik Percepatan Setiap Variasi Pegas Pada Tingkat Transmisi Ketiga.

\section{F. Grafik Gaya Dorong dan Percepatan Setiap Variasi Pegas Pada Tingkat Transmisi Keempat.}

Berikut ini adalah grafik perbandingan gaya dorong dan percepatan kendaraan pada tingkat transmisi keempat. Pada grafik gaya dorong yang ditunjukkan oleh gambar 18 terlihat bahwa pegas dengan nilai konstanta 13,05 N/mm menghasilkan gaya dorong terbesar dibandingkan dengan ketiga pegas lainnya yaitu sebesar 181,838 N.

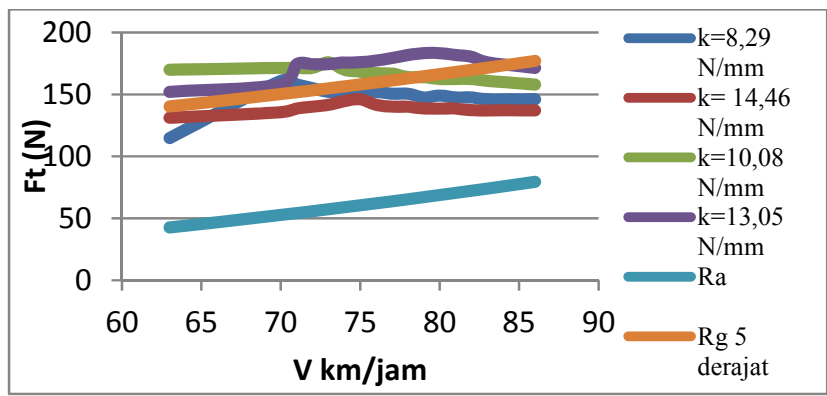

Gambar 18. Grafik Gaya Dorong Beserta Gaya Hambat Setiap Variasi Pegas Pada Tingkat Transmisi Keempat.

Pada gambar 19 menunjukkan grafik perbandingan percepatan setiap pegas kopling pada tingkat transmisi keempat dimana pegas dengan nilai konstanta 13,05 N/mm menghasilkan nilai percepatan terbesar sebesar $1,11 \mathrm{~m} / \mathrm{s}^{2}$. Hingga tingkatan transmisi keepat pegas dengan nilai $13,05 \mathrm{~N} / \mathrm{mm}$ unggul dibandingkan keempat pegas lainnya karena pengaruh dari tingkat kekakuan pegas dan kendaraan berada pada kondisi prima. 


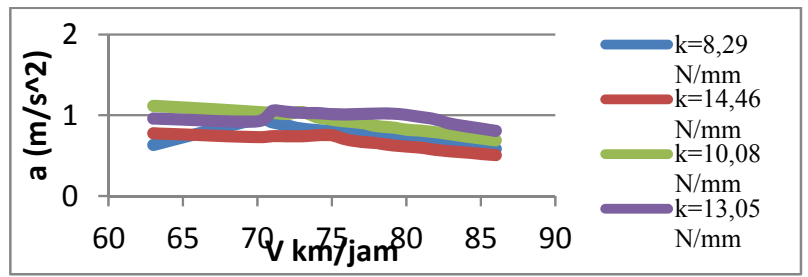

Gambar 19. Grafik Percepatan Setiap Variasi Pegas Pada Tingkat Transmisi Keempat.

\section{G. Grafik Gaya Dorong dan Percepatan Setiap Variasi Pegas Pada Tingkat Transmisi Kelima.}

Berikut ini adalah grafik perbandingan gaya dorong dan percepatan pada tingkat transmisi kelima. Dimana pada gambar 18 menunjukkan grafik perbandingan gaya dorong setiap variasi pegas kopling dimana pegas dengan 13,05 $\mathrm{N} / \mathrm{mm}$ menghasilkan nilai gaya dorong yang terbesar yaitu sebesar $153,839 \mathrm{~N}$ dibandingkan dengan pegas $8,29 \mathrm{~N} / \mathrm{mm}$, $10,08 \mathrm{~N} / \mathrm{mm}$ dan 14,46N/mm. Pengaruh kondisi kendaraan yang prima menjadi alasan mengapa pegas dengan nilai $13,05 \mathrm{~N} / \mathrm{mm}$ memiliki konsistensi pada setiap tingkat transmisi selain dari pengaruh panjang pegas dan nilai konstanta pegas pada kendaraan.

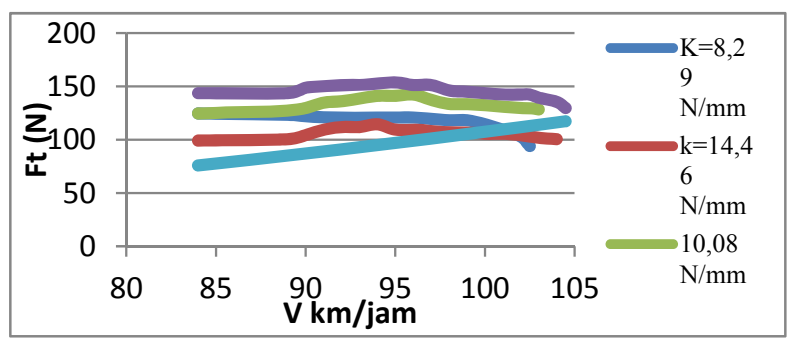

Gambar 20. Grafik Gaya Dorong Beserta Gaya Hambat Setiap Variasi Pegas Pada Tingkat Transmisi Kelima

Pada gambar 21 ditunjukkan grafik perbandingan nilai percepatan pada kendaraan, dimana pegas dengan nilai konstanta $13,05 \mathrm{~N} / \mathrm{mm}$ menghasilkan nilai percepatan yang terbesar yaitu sebesar $0,59 \mathrm{~m} / \mathrm{s}^{2}$. Hal yang mempengaruhi adalah besarnya nilai gaya dorong yang dihasilkan dari pegas kopling .

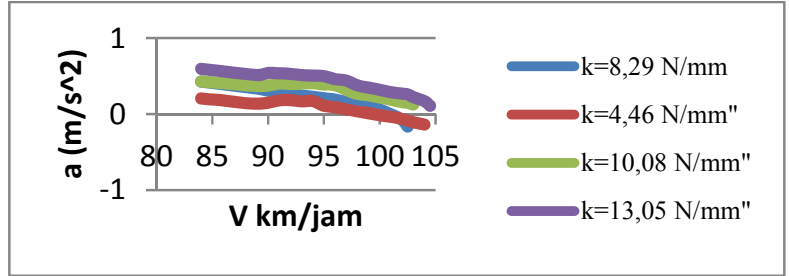

Gambar 21. Grafik Percepatan Setiap Variasi Pegas Pada Tingkat Transmisi Kelima

\section{KESIMPULAN/RINGKASAN}

Dari analisa yang telah dilakukan menggunakan kendaraan Yamaha Vixion $150 \mathrm{cc}$ dengan menggunakan variasi pegas kopling dengan variasi $8,29 \mathrm{~N} / \mathrm{mm}, 13,05 \mathrm{~N} / \mathrm{mm}$ dapat ditarik kesimpulan antara lain :

1. Semakin besar nilai konstanta pegas yang digunakan, nilai gaya dorong yang dihasilkan oleh pegas kopling tersebut juga besar karena, pada kendaraan tercipta suatu cengkeraman yang lebih kuat antar pegas kopling dan kampas kopling yang menyebabkan putaran mesin dapat tersalur baik dari crankshaft ke poros transmisi.

2. Dengan menggunakan pegas kopling dengan nilai konstanta yang besar, akselerasi yang dihasilkan akan semakin baik karena, dengan menggunakan pegas kopling yang memiliki nilai kontanta yang besar pertambahan kecepatan pada setiap tingkatan transmisi akan semakin baik berbeda dengan pegas kopling yang memiliki nilai konstanta yang kecil atau lebih lentur.

3. Pada tingkatan transmisi pertama nilai gaya dorong dan percepatan yang dihasilkan oleh pegas dengan nilai konstanta 13,05 N/mm sebesar 509,805 $\mathrm{N}$ dan $5,18 \mathrm{~m} / \mathrm{s}^{2}$. Sedangkan pada tingkatan transmisi kedua hingga kelima pegas kopling dengan nilai konstanta pegas $13,05 \mathrm{~N} / \mathrm{mm}$ mendominasi dengan menghasilkan nilai gaya dorong dan percepatan yang baik dibandingkan dengan ketiga variasi pegas kopling lainnya yaitu sebesar 320,295 $\mathrm{N}$ dan 2,64 $\mathrm{m} / \mathrm{s}^{2}, 232,927 \mathrm{~N}$ dan $1,74 \mathrm{~m} / \mathrm{s}^{2}, 181,838 \mathrm{~N}$ dan 1,11 $\mathrm{m} / \mathrm{s}^{2}, 153,839 \mathrm{~N}$ dan $0,59 \mathrm{~m} / \mathrm{s}^{2}$.

\section{DAFTAR PUSTAKA}

[1] Sutantra, I.N., \& Bambang Sampurno. (2010). Teknologi Otomotif Edisi Kedua. Surabaya: Guna Widya.

[2] Deutchman, Aaron D. (1975). Machine Design : Theory and Practice. New York: Macmilan Publishing co, Inc

[3] Ardiansyah Sandy \& Wulandari Dian (2010). Pengaruh Variasi Pegas Kopling Pada Kendaraan Yamaha Jupiter Z Terhadap performa Kendaraan.

[4] Habibullah, M.Akif . 2016 . Studi Eksperimen Variasi Roller 7 Gram , 10 Gram , 11 Gram dan 12 Gram Pada Continously Variable Transmission ( CVT) Terhadap Kinerja Traksi dan Percepatan Dari Kendaraan Honda Scoopy 110 cc. Surabaya: Institut Teknologi Sepuluh Nopember.

[5] R C Lam and Y Yang. 'Prediction of Torque Response during the Engagement of Wet Friction Clutch.' SAE Technical Paper 981097, 1998.

[6] S.Jaya Kishore, M.Lava kumar, "Structural Analysis of Multi Plate Clutch", International Journal of Computer Trends and Technology(IJCTT), Volume 4 Issue 7-July 2014. 